\title{
THE URINARY EXCRETION OF THIAMINE AS AN INDEX OF THE NUTRITIONAL LEVEL: ASSESSMENT OF THE VALUE OF A TEST DOSE
}

\author{
By HAROLD L. MASON AND RAY D. WILLIAMS \\ (From the Division of Biochemistry, Mayo Foundation, Rochester, Minnesota)
}

(Received for publication November 3, 1941)

Harris and Leong (1), in 1936, suggested that the state of vitamin $B_{1}$ deficiency in man could be detected by measurement of the amount of the vitamin excreted in the urine in the twenty-fourhour period following a single oral test dose of 900 micrograms of thiamine chloride, and since then many other procedures have been suggested for the detection of vitamin $B_{1}$ deficiency by means of a test dose (2 to 8 ). Oral and parenteral routes have been used for administration of test doses varying from 1 to $10 \mathrm{mgm}$. of thiamine chloride and various criteria have been set up for estimation of the state of the subject's nutrition with respect to vitamin $B_{1}$.

The value of a laboratory test for vitamin $\mathrm{B}_{1}$ deficiency lies largely in its application to the detection of those cases in which a chronic mild deficiency may have existed for some time but in which cleancut symptoms or signs of deficiency are not evident. The urinary excretion of thiamine under various conditions has been used as a suggestive index of the state of thiamine nutrition but, unfortunately, most of the control tests reported in the literature have been made on persons partaking of their customary diets of unknown or unspecified vitamin $B_{1}$ content, or on hospital patients. We believe that it is necessary to determine the response to the test of individuals maintained on various levels of thiamine intake for varying periods of time in order to assess the validity of the test. Only in this way can the response be correlated satisfactorily with the nutritional history and clinical state.

We are prompted to report our experience with test-dose procedures because we have had the opportunity to study the responses of fifteen female subjects maintained on rigidly controlled diets of known thiamine content for intervals varying from thirteen weeks to five months. Factors of the vitamin B complex other than thiamine were supplied in purified form or in the form of autoclaved yeast; therefore, the dietary restriction was limited as nearly as possible to thiamine alone. Since the duration and degree of deficiency were known accurately, we believe that the value of test-dose procedures or of the ordinary twentyfour-hour excretion of thiamine as a laboratory aid can be accurately assessed.

\section{EXPERIMENTAL}

The present study is part of a larger one on induced thiamine deficiency in human subjects. The selection of subjects and the diets utilized in this study have been described in previous reports $(9,10,11)$. Two groups of four women each, who agreed to serve as subjects for this study, were fed a diet which contained not more than 150 micrograms per day of thiamine, and a third group of eleven women were fed a diet which furnished 400 to 450 micrograms of thiamine per day.

Test-dose procedure. There is no agreement as to the amount of thiamine that should be used for a test dose or as to the mode of administration. Intramuscular injection was chosen as the mode of administration since it insured complete and rapid absorption. A test dose of 1 mgm. (1000 micrograms) of thiamine chloride was chosen since it was sufficiently large for the purpose but not large enough to flood the system when rapidly absorbed. The results confirm the adequacy of this procedure.

Collection of urine. Urine was collected in bottles which contained $15 \mathrm{cc}$. of glacial acetic acid, an amount sufficient to bring the $\mathrm{pH}$ of a twenty-four-hour specimen to about 4. Specimens were collected during the twentyfour hours just preceding and again immediately following the injection of the test dose. The thiamine content was determined by the method of Hennessy and Cerecedo (12), revised by Hennessy (13).

\section{RESULTS}

Table I shows the values of thiamine excretion in two groups of four subjects who were maintained on a diet which contained not more than 150 micrograms of thiamine per day. The first group (Subjects 1 to 4 ) received the test dose after 155 days and again after 169 days at this intake level. Symptoms of severe deficiency of 
thiamine were evident on both occasions. The results of the test were essentially the same in both instances. The excretions of thiamine in the twenty-four hours preceding the test were 11 to 26 micrograms. ${ }^{1}$ In the twenty-four hours following the injection of the test dose of 1000 micrograms, the amounts of thiamine (extra thiamine) excreted over and above those in the preceding twenty-four hours were 2 to 6 per cent of the amount injected. Following a subsequent period of seventeen days during which $10 \mathrm{mgm}$. of thiamine chloride and 10 grams of brewers' yeast were given as daily supplements to an unrestricted diet, the intake of thiamine was again restricted to 850 micrograms for seventeen days. On the last three days of this period the average (pooled specimens) twenty-four-hour excretions of thiamine were 124 to 256 micrograms and on the eighteenth day the extra excretions after the test dose were 15 to 45 per cent of the dose.

The second group of subjects $(5,6,8$ and 9) received the test dose after they had consumed the diet containing 150 micrograms of thiamine for eighty-eight days, at which time symptoms of severe deficiency of thiamine were evident. The results were similar to those obtained in the first group. After a thirty-three-day period of unrestricted diet with supplements of brewers' yeast and thiamine chloride (15 mgm. for eight days, then $5 \mathrm{mgm}$. for twenty-five days) the intake of thiamine was restricted to 850 micrograms for five days. On the fifth day the excretions were 254 to 400 micrograms and on the sixth day 23 to 26 per cent of the test dose was excreted in the urine. The intake of thiamine was further restricted to 150 micrograms for five days. The excretions during twenty-four hours fell to values between 35 and 75 micrograms and on the fifth day the extra excretions after the test dose were 12 to 17 per cent of the dose.

These results indicate a rapid loss of the thiamine stored during the period of excessive intake. The values of 254 to 400 micrograms are much higher than the values that would normally be found for the thiamine excretion when the intake is 850 micrograms. After restriction of the intake to 150 micrograms the values of $35,41,45$, and

\footnotetext{
1 Values of this order, although expressed as thiamine, may be largely due to the presence of metabolic products of nicotinic acid (14).
}

75 micrograms for the ordinary excretion are definitely within the range indicative of a deficient intake of thiamine. Although the recoveries of 12 to 17 per cent of the test dose are also subnormal, they reflect a better state of nutrition with respect to thiamine than the values for the ordinary excretion.

Melnick, Field and Robinson (15) also have observed elevated values for the excretion of thiamine for some days after ingestion of large amounts of thiamine chloride. They recommended that two weeks be allowed to elapse between termination of the excessive intake of thiamine and a study of the excretion. It will be shown later that evidence of storage of thiamine may be found in the ordinary excretion and in the response to the test dose as long as four weeks after restriction of the intake to 400 to 600 micrograms.

The third group of eleven subjects $(5,6$ and 8 to 16; Table II), after a preliminary control period with an intake of 850 micrograms of thiamine daily, were fęd a diet containing 450 micrograms of thiamine in order to study the effects of a chronic deficiency as compared with the acute deficiency produced in earlier studies. The low excretions of thiamine during the control period by Subjects 8, 9, 10 and 15 indicate that a daily intake of 850 micrograms of thiamine was insufficient for these subjects at this time. Subjects 5, 6, 8, 9 and 10 were used in the previous study in which the thiamine intake was restricted to 150 micrograms. At the beginning of the previous study the excretions of thiamine indicated that an intake of 850 micrograms of thiamine was adequate, although the period of measured intake at this level was only six days as compared with sixteen days in this later study. A period of fifty-four days had elapsed between the two studies and during fifty days these subjects were allowed an unrestricted diet supplemented with $2.5 \mathrm{mgm}$. of thiamine chloride and 10 grams of brewers' yeast daily. Just prior to the second study the thiamine supplement was increased to $7.5 \mathrm{mgm}$. for four days. The excretions of thiamine by these subjects $(5,6,8,9$ and 10) did not differ significantly from the excretions of the other subjects of Table II who had received only the ordinary institutional diet prior to the period of study. There is thus no indication in 
URINARY EXCRETION OF THIAMINE

TABLE I

Excretion of thiamine before and after a test dose when the diet furnished 150 micrograms of thiamine

\begin{tabular}{|c|c|c|c|c|c|c|c|c|c|}
\hline Subject & Age & Weight & Height & $\begin{array}{l}\text { Thiamine } \\
\text { content } \\
\text { of diet }\end{array}$ & $\begin{array}{c}\text { Interval } \\
\text { of intake } \\
\text { level }\end{array}$ & $\begin{array}{l}\text { Twenty-four- } \\
\text { hour excretion } \\
\text { before injection } \\
\text { of } 1 \mathrm{mgm} \text {. of } \\
\text { thiamine }\end{array}$ & $\begin{array}{l}\text { Twenty-four- } \\
\text { hour excretion } \\
\text { after injection } \\
\text { of } 1 \text { mgm. of } \\
\text { thiamine }\end{array}$ & $\begin{array}{l}\text { Extra } \\
\text { excretion } \\
\text { after } \\
\text { test } \\
\text { dose }\end{array}$ & $\begin{array}{l}\text { Extra } \\
\text { excretion } \\
\text { after } \\
\text { test } \\
\text { dose }\end{array}$ \\
\hline 1 & $\begin{array}{c}\text { years } \\
29\end{array}$ & $\begin{array}{c}\text { kgm. } \\
57\end{array}$ & $\begin{array}{l}\mathrm{cm} . \\
163\end{array}$ & $\begin{array}{c}\text { micrograms } \\
700 \\
150 \\
150 \\
>10000 \\
850 \dagger\end{array}$ & $\begin{array}{c}\text { days } \\
* \\
155 \\
169 \\
17 \\
17\end{array}$ & $\begin{array}{c}\text { micrograms } \\
99 \\
15 \\
26 \\
124\end{array}$ & $\begin{array}{c}\text { micrograms } \\
\qquad \begin{array}{r}75 \\
81 \\
458\end{array}\end{array}$ & $\begin{array}{c}\text { micrograms } \\
\qquad \begin{array}{c}60 \\
55 \\
\\
334\end{array}\end{array}$ & $\begin{array}{c}\text { per cent of } \\
\text { test dose } \\
6 \\
6 \\
6 \\
33\end{array}$ \\
\hline 2 & 21 & 54 & 157 & $\begin{array}{r}700 \\
150 \\
150 \\
>10000 \\
850 \dagger\end{array}$ & $\begin{array}{r}* \\
155 \\
169 \\
17 \\
17\end{array}$ & $\begin{array}{r}90 \\
19 \\
12 \\
\\
124\end{array}$ & $\begin{array}{r}49 \\
44 \\
570\end{array}$ & $\begin{array}{r}30 \\
32 \\
446\end{array}$ & $\begin{array}{r}3 \\
3 \\
45\end{array}$ \\
\hline 3 & 25 & 46 & 160 & $\begin{array}{r}700 \\
150 \\
150 \\
>10000 \\
850 \dagger\end{array}$ & $\begin{array}{r}* \\
155 \\
169 \\
17 \\
17\end{array}$ & $\begin{array}{r}90 \\
11 \\
12 \\
256\end{array}$ & $\begin{array}{r}63 \\
31 \\
\\
405\end{array}$ & $\begin{array}{r}52 \\
19 \\
\\
149\end{array}$ & $\begin{array}{r}5 \\
2 \\
15\end{array}$ \\
\hline 4 & 24 & 51 & 157 & $\begin{array}{r}700 \\
150 \\
150 \\
>10000 \\
850 \dagger\end{array}$ & $\begin{array}{r}* \\
155 \\
169 \\
17 \\
17\end{array}$ & $\begin{array}{r}105 \\
11 \\
21 \\
172\end{array}$ & $\begin{array}{r}72 \\
80 \\
473\end{array}$ & $\begin{array}{r}61 \\
59 \\
\\
301\end{array}$ & $\begin{array}{r}6 \\
6 \\
30\end{array}$ \\
\hline 5 & 23 & 57 & 162 & $\begin{array}{r}850 \\
150 \\
150 \\
>\quad 5000 \\
850 \\
150\end{array}$ & $\begin{array}{r}6 \\
68 \\
88 \\
33 \\
5 \\
4\end{array}$ & $\begin{array}{r}320 \\
30 \\
17 \\
\\
400 \\
35\end{array}$ & $\begin{array}{r}79 \\
32 \\
\\
652 \\
208\end{array}$ & $\begin{array}{r}49 \\
15 \\
\\
252 \\
173\end{array}$ & $\begin{array}{r}5 \\
2 \\
25 \\
17\end{array}$ \\
\hline 6 & 33 & 51 & 158 & $\begin{array}{r}850 \\
150 \\
>\quad 5000 \\
850 \\
150\end{array}$ & $\begin{array}{r}6 \\
88 \\
33 \\
5 \\
4\end{array}$ & $\begin{array}{r}124 \\
7 \\
\\
385 \\
41\end{array}$ & $\begin{array}{r}69 \\
613 \\
181\end{array}$ & $\begin{array}{r}62 \\
228 \\
140\end{array}$ & $\begin{array}{r}6 \\
23 \\
14\end{array}$ \\
\hline 8 & 46 & 48 & 161 & $\begin{array}{r}850 \\
150 \\
>\quad 5000 \\
850 \\
150\end{array}$ & $\begin{array}{r}6 \\
88 \\
33 \\
5 \\
4\end{array}$ & $\begin{array}{r}98 \\
9 \\
255 \\
45\end{array}$ & $\begin{array}{r}40 \\
510 \\
166\end{array}$ & $\begin{array}{r}31 \\
255 \\
121\end{array}$ & $\begin{array}{r}3 \\
26 \\
12\end{array}$ \\
\hline 9 & 26 & 70 & 159 & $\begin{array}{r}850 \\
150 \\
>\quad 5000 \\
850 \\
150\end{array}$ & $\begin{array}{r}6 \\
88 \\
33 \\
5 \\
4\end{array}$ & $\begin{array}{r}68 \\
9 \\
254 \\
75\end{array}$ & $\begin{array}{r}22 \\
230\end{array}$ & $\begin{array}{r}13 \\
155\end{array}$ & $\begin{array}{r}1 \\
16\end{array}$ \\
\hline
\end{tabular}

* The customary institutional diet of the subject was calculated to contain 650 to 750 micrograms of thiamine. A preliminary period of measured diet was not obtained.

† After the period of restricted intake of thiamine the diet was unrestricted and was supplemented with 10 mgm. of thiamine chloride and 10 grams of brewers' yeast daily, September 12 to 29, 1939 . A controlled diet which contained 850 micrograms was instituted September 29. The test was conducted October 16, 1939.

the excretions of a store of thiamine. Unfor- of thiamine to 450 micrograms. The values for tunately, a test dose was not given at this time.

In Table II are presented the results of the administration of the test dose twenty-eight and ninety-eight days after restriction of the intake the ordinary twenty-four-hour excretions on the twenty-eighth day are within the range of 10 to 33 micrograms, with an average value of $16 \mathrm{mi}-$ crograms. The values for the ninety-eighth day 
TABLE II

Excretion of thiamine before and after a test dose when the diet furnished 450 micrograms of thiamine

\begin{tabular}{|c|c|c|c|c|c|c|c|c|c|}
\hline Subject & Age & Weight & Height & $\begin{array}{l}\text { Thiamine } \\
\text { content } \\
\text { of diet }\end{array}$ & $\begin{array}{c}\text { Interval } \\
\text { of intake } \\
\text { level }\end{array}$ & $\begin{array}{l}\text { Twenty-four- } \\
\text { hour excretion } \\
\text { before injection } \\
\text { of } 1 \mathrm{mgm} \text {. of } \\
\text { thiamine }\end{array}$ & $\begin{array}{l}\text { Twenty-four- } \\
\text { hour excretion } \\
\text { after injection } \\
\text { of } 1 \text { mgm. of } \\
\text { thiamine }\end{array}$ & $\begin{array}{c}\text { Extra } \\
\text { excretion } \\
\text { of thiamine } \\
\text { after } \\
\text { test } \\
\text { dose }\end{array}$ & $\begin{array}{c}\text { Extra } \\
\text { excretion } \\
\text { of thiamine } \\
\text { after } \\
\text { test } \\
\text { dose }\end{array}$ \\
\hline & years & kgm. & $c m$. & micrograms & days & micrograms & micrograms & micrograms & $\begin{array}{l}\text { per cent of } \\
\text { test dose }\end{array}$ \\
\hline 5 & 23 & 57 & 162 & $\begin{array}{l}850 \\
450 \\
450\end{array}$ & $\begin{array}{l}16 \\
28 \\
98\end{array}$ & $\begin{array}{r}135 \\
14 \\
24\end{array}$ & $\begin{array}{l}110 \\
116\end{array}$ & $\begin{array}{l}96 \\
92\end{array}$ & $\begin{array}{r}10 \\
9\end{array}$ \\
\hline 6 & 33 & 51 & 158 & $\begin{array}{l}850 \\
450 \\
450\end{array}$ & $\begin{array}{l}16 \\
28 \\
98\end{array}$ & $\begin{array}{r}128 \\
10 \\
18\end{array}$ & $\begin{array}{l}77 \\
89\end{array}$ & $\begin{array}{l}67 \\
71\end{array}$ & $\begin{array}{l}7 \\
7\end{array}$ \\
\hline 8 & 46 & 48 & 161 & $\begin{array}{l}850 \\
450 \\
450\end{array}$ & $\begin{array}{l}16 \\
28 \\
98\end{array}$ & $\begin{array}{l}64 \\
14 \\
23\end{array}$ & $\begin{array}{l}85 \\
60\end{array}$ & $\begin{array}{l}71 \\
37\end{array}$ & $\begin{array}{l}7 \\
4\end{array}$ \\
\hline 9 & 26 & 70 & 159 & $\begin{array}{l}850 \\
450 \\
450\end{array}$ & $\begin{array}{l}16 \\
28 \\
98\end{array}$ & $\begin{array}{l}74 \\
19 \\
21\end{array}$ & $\begin{array}{l}75 \\
30\end{array}$ & $\begin{array}{r}56 \\
9\end{array}$ & $\begin{array}{l}6 \\
1\end{array}$ \\
\hline 10 & 28 & 53 & 154 & $\begin{array}{l}850 \\
450\end{array}$ & $\begin{array}{l}16 \\
28\end{array}$ & $\begin{array}{l}73 \\
17\end{array}$ & 55 & 38 & 4 \\
\hline 11 & 39 & 49 & 158 & $\begin{array}{l}850 \\
450 \\
450\end{array}$ & $\begin{array}{l}16 \\
28 \\
98\end{array}$ & $\begin{array}{r}136 \\
16 \\
14\end{array}$ & $\begin{array}{l}116 \\
104\end{array}$ & $\begin{array}{r}100 \\
90\end{array}$ & $\begin{array}{r}10 \\
9\end{array}$ \\
\hline 12 & 39 & 53 & 168 & $\begin{array}{l}850 \\
450 \\
450\end{array}$ & $\begin{array}{r}20 \\
28 \\
105\end{array}$ & $\begin{array}{l}96 \\
11 \\
18\end{array}$ & $\begin{array}{r}126 \\
21\end{array}$ & $\begin{array}{r}115 \\
3\end{array}$ & $\begin{array}{r}12 \\
<1\end{array}$ \\
\hline 13 & 37 & 85 & 157 & $\begin{array}{l}850 \\
450 \\
450\end{array}$ & $\begin{array}{l}20 \\
28 \\
98\end{array}$ & $\begin{array}{r}100 \\
33 \\
23\end{array}$ & $\begin{array}{l}86 \\
63\end{array}$ & $\begin{array}{l}53 \\
40\end{array}$ & $\begin{array}{l}5 \\
4\end{array}$ \\
\hline 14 & 45 & 55 & 166 & $\begin{array}{l}850 \\
450 \\
450\end{array}$ & $\begin{array}{l}20 \\
28 \\
98\end{array}$ & $\begin{array}{r}140 \\
19 \\
16\end{array}$ & $\begin{array}{l}95 \\
93\end{array}$ & $\begin{array}{l}76 \\
77\end{array}$ & $\begin{array}{l}8 \\
8\end{array}$ \\
\hline 15 & 41 & 68 & 173 & $\begin{array}{l}850 \\
450 \\
450\end{array}$ & $\begin{array}{r}9 \\
28 \\
98\end{array}$ & $\begin{array}{l}57 \\
13 \\
28\end{array}$ & $\begin{array}{l}85 \\
94\end{array}$ & $\begin{array}{l}72 \\
66\end{array}$ & $\begin{array}{l}7 \\
7\end{array}$ \\
\hline 16 & 23 & 65 & 172 & $\begin{array}{l}850 \\
450 \\
450\end{array}$ & $\begin{array}{l}20 \\
28 \\
98\end{array}$ & $\begin{array}{l}86 \\
12 \\
21\end{array}$ & $\begin{array}{r}110 \\
92\end{array}$ & $\begin{array}{l}98 \\
71\end{array}$ & $\begin{array}{r}10 \\
7\end{array}$ \\
\hline
\end{tabular}

tend to be a little higher, with a range of 14 to 28 micrograms and an average value of 21 micrograms. The extra excretions after the test dose are well below those obtained with subjects with an adequate intake of thiamine. Three of the values (Subjects 9, 10 and 13) for the extra excretion following the test dose obtained after twenty-eight days are within the range of values ( 1 to 6 per cent of the dose) obtained with the subjects who had been given only 150 micrograms of thiamine daily for three to five months (Table I). Four values (Subjects 5, 6, 8 and 14) were outside this range by only 1 or 2 per cent and four were in the range of 10 to 12 per cent. There were no very significant changes in the responses to the test dose after an additional period of seventy days on the same restricted intake of thiamine with the exception of Subjects 9 and 12. These two subjects returned less than 1 per cent of the test dose after ninety-eight days. At the end of the ninety-eight-day period, symptoms of thiamine deficiency were observed in all cases.

Six of the eleven subjects included in Table II were selected for study of the thiamine requirement of normal persons. However, one of the 
subjects became unable to cooperate satisfactorily as a result of the previous restrictions of thiamine and, therefore, only five subjects are considered here. Two of them ( 5 and 6 ) had been given $7.5 \mathrm{mgm}$. of thiamine chloride from December 4, 1940 to January 9, 1941 (thirty-seven days). These two subjects had had opportunity to store maximal amounts of thiamine and were free from any signs of deficiency. The other three subjects had been maintained for 169 days on an intake of less than 450 micrograms daily, and their stores were undoubtedly depleted. On January 10, 1941, and thereafter until June 1, 1941, the intakes of thiamine of all five subjects were identical. The basic diet was continued and increasing amounts of thiamine chloride were given. A given level of thiamine intake was maintained until the excretions became relatively constant. The average of the values for the daily excretions at the various levels of intake is given in Table III; also the results of the test dose procedures are given in terms of percentage of the dose. The group averages of the daily excretions are presented graphically in Figure 1. It will be observed that the excretions by Subjects 5 and 6 fell to approximately the same level as the excretions of the other three subjects at the intake level of 800 micrograms and then all excretions increased at about the same rate as the intake increased. The 1esponse of Subjects 5 and 6 (Table III) to the test dose was essentially constant until the intake reached 800 to 1000 micrograms, after which the proportion of the test dose recovered in the urine rose to an average of 39 per cent of the dose when the intake was $2 \mathrm{mgm}$. The response of Subjects 12, 13 and 16 followed a similar pattern after the intake level reached 800 micrograms. At the lower levels of thiamine intake the recovery of the test dose was much less than in the case of Subjects 5 and 6 . There are unexplained fluctuations, possibly the result of technical errors, in the response to the test dose. For example, the responses of Subjects 13 and 16 show a sudden fall when the level of intake is 1000 micrograms, but this loss is more than made up in the determination at the next level of intake.

The sudden jump in the amount of thiamine excreted when the intake was increased from 800 to 1000 micrograms is worthy of note. The previous increment of 200 micrograms (from 600 to 800 ) produced an average increase of 45 micrograms in the excretion by Subjects 12, 13 and 16, while the excretions by Subjects 5 and 6 diminished. The next increment (from 800 to 1000), however, reversed the trend of Subjects 5 and 6 and produced an increase of 105 micrograms in the average excretion of all subjects. This finding suggests that a level of intake of 800 micrograms was just enough for physiologic purposes and that above this level a greater amount was excreted as surplus. Excretion of an average of 39 per cent of the amount ingested when the intake was 2000 micrograms indicates a considerable waste of thiamine at this level.

Since the results of Table III were obtained when all of the ingested thiamine over 400 micro-

TABLE III

Excretion of thiamine during maintenance at different levels of thiamine intake

\begin{tabular}{|c|c|c|c|c|c|c|c|c|c|c|}
\hline \multirow{3}{*}{$\begin{array}{l}\text { Daily } \\
\text { intake of } \\
\text { thiamine }\end{array}$} & \multicolumn{4}{|c|}{ Good stores } & \multicolumn{6}{|c|}{ Poor stores } \\
\hline & \multicolumn{2}{|c|}{ Subject 5} & \multicolumn{2}{|c|}{ Subject 6} & \multicolumn{2}{|c|}{ Subject 12} & \multicolumn{2}{|c|}{ Subject 13} & \multicolumn{2}{|c|}{ Subject 16} \\
\hline & $\begin{array}{c}\text { Average } \\
\text { daily } \\
\text { excretion }\end{array}$ & $\begin{array}{l}\text { Recovery } \\
\text { of test } \\
\text { dose }\end{array}$ & $\begin{array}{c}\text { Average } \\
\text { daily } \\
\text { excretion }\end{array}$ & $\begin{array}{l}\text { Recovery } \\
\text { of test } \\
\text { dose }\end{array}$ & $\begin{array}{c}\text { Average } \\
\text { daily } \\
\text { excretion }\end{array}$ & $\begin{array}{c}\text { Recovery } \\
\text { of test } \\
\text { dose }\end{array}$ & $\begin{array}{c}\text { Average } \\
\text { daily } \\
\text { excretion }\end{array}$ & $\begin{array}{l}\text { Recovery } \\
\text { of test } \\
\text { dose }\end{array}$ & $\begin{array}{c}\text { Average } \\
\text { daily } \\
\text { excretion }\end{array}$ & $\begin{array}{c}\text { Recovery } \\
\text { of test } \\
\text { dose }\end{array}$ \\
\hline $\begin{array}{c}\text { micrograms } \\
400 \\
600 \\
800 \\
1000 \\
1200 \\
1400 \\
1600 \\
1800 \\
2000\end{array}$ & \begin{tabular}{|c|} 
micrograms \\
434 \\
196 \\
152 \\
241 \\
282 \\
424 \\
669 \\
699 \\
858
\end{tabular} & $\begin{array}{c}\text { per cent } \\
17.6 \\
20.0 \\
21.2 \\
18.6 \\
28.6 \\
30.9 \\
36.5 \\
42.0 \\
32.3\end{array}$ & \begin{tabular}{|c} 
micrograms \\
386 \\
233 \\
126 \\
216 \\
239 \\
309 \\
498 \\
547 \\
786
\end{tabular} & $\begin{array}{c}\text { per cent } \\
\\
20.3 \\
19.7 \\
26.6 \\
27.7 \\
25.4 \\
35.7 \\
44.9 \\
46.1\end{array}$ & \begin{tabular}{|c|} 
micrograms \\
33 \\
71 \\
128 \\
133 \\
264 \\
403 \\
581 \\
591 \\
770
\end{tabular} & $\begin{array}{c}\text { per cent } \\
14.2 \\
17.2 \\
24.6 \\
25.0 \\
10.8 \\
21.7 \\
42.6 \\
24.4 \\
52.1\end{array}$ & \begin{tabular}{|c} 
micrograms \\
53 \\
57 \\
90 \\
243 \\
219 \\
335 \\
498 \\
596 \\
740
\end{tabular} & $\begin{array}{c}\text { per cent } \\
7.6 \\
17.4 \\
21.3 \\
12.9 \\
25.8 \\
25.3 \\
25.8 \\
36.5 \\
19.1\end{array}$ & $\begin{array}{c}\text { micrograms } \\
47 \\
52 \\
101 \\
190 \\
202 \\
287 \\
557 \\
590 \\
731\end{array}$ & $\begin{array}{c}\text { per cent } \\
11.0 \\
13.7 \\
18.9 \\
12.4 \\
24.7 \\
17.2 \\
31.9 \\
39.0 \\
45.8\end{array}$ \\
\hline
\end{tabular}




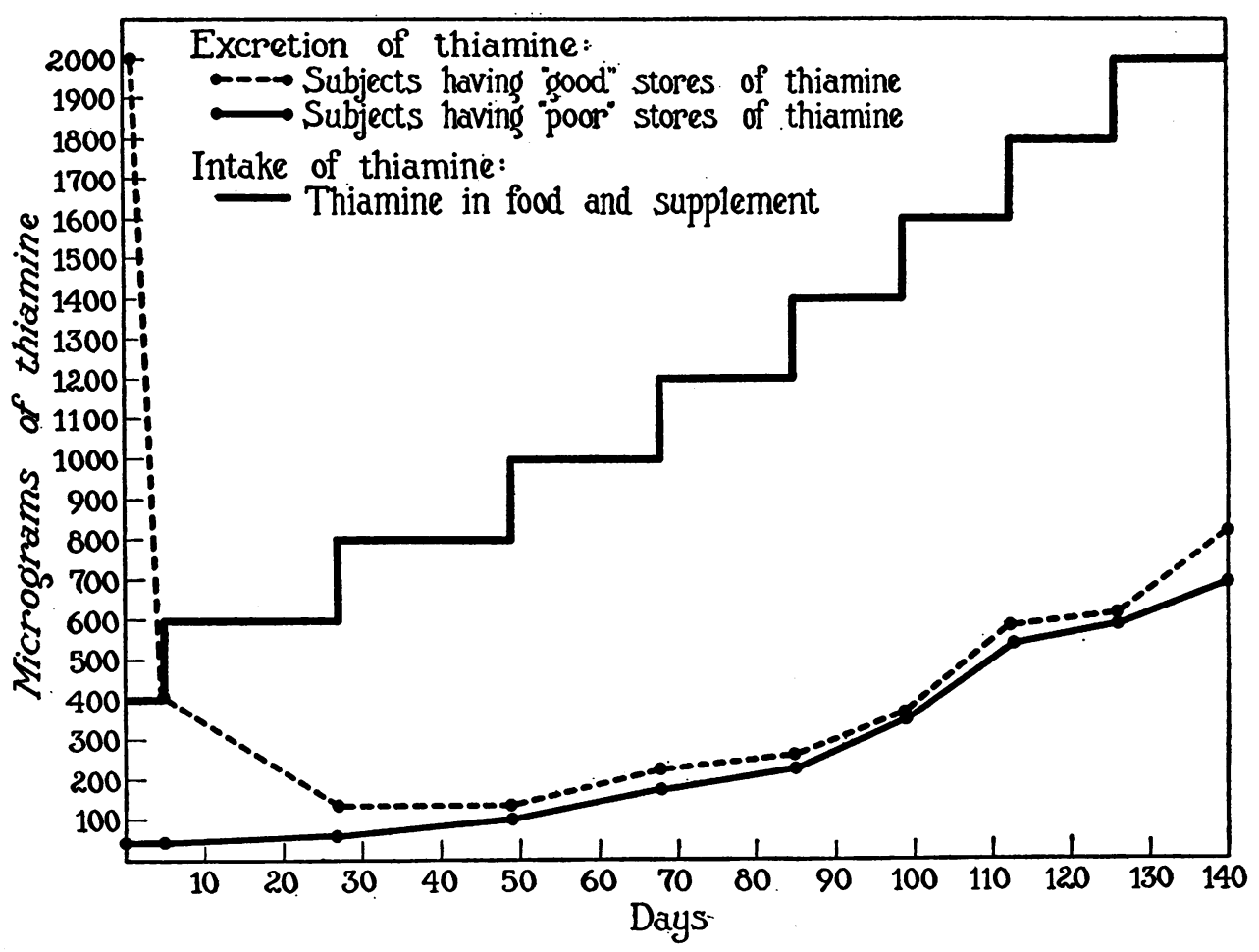

Fig. 1. Excretion of Thiamine in the Urine During Study of Requirement of Thiamine

grams was in the form of a solution of thiamine chloride, it was necessary to determine the excretions when all of the ingested thiamine was derived from the food. When diets, which contained 1000,1500 and 2000 micrograms of thiamine in the component foods, were consumed, the values for the urinary excretions of thiamine were within the range of values recorded in Table III at these same levels of intake. It thus appears that thiamine is utilized as effectively when it is ingested as an aqueous solution of thiamine chloride as when it is ingested as natural vitamin $B_{1}$ in foodstuffs.

There are many occasions when complete collection of urine for twenty-four hours is inconvenient or even impossible, whereas collection for a period of four hours should be readily obtained. A further study of the four-hour test is under way to determine the relation between the nutritional state with respect to thiamine and the magnitude of the response to the test dose with a four-hour collection of urine.

\section{COMMENT}

Examination of the data presented in Table I reveals that after 169 and eighty-eight days of the severe restriction of thiamine, at which times a state of vitamin $B_{1}$ deficiency was well developed in all cases, the extra excretion of thiamine after the test dose was 1 to 6 per cent of the dose. It also should be noted that at this time the ordinary twenty-four-hour excretions were within the range of 7 to 26 micrograms. It will be observed that when the nutrition with respect to thiamine was adequate the response to the test dose with one exception (Subject 3) resulted in values for the extra excretion of thiamine of more than 20 per cent of the dose. There is thus a distinct separation of the response of the subjects in a state of marked thiamine deficiency from the response of those receiving an adequate supply of thiamine. However, the greatest value of a laboratory test as an aid to diagnosis would lie in its application to those borderline cases in which frank symptoms of a state of deficiency are not evident.

The value of measurement of the excretion of thiamine and of the test-dose procedure may be estimated by consideration of the clinical condition of the subjects in Table II in conjunction with the laboratory data. Fatigue, lassitude, anorexia and mental depression were evident in some instances 
at the twenty-eighth day but a definite diagnosis of thiamine deficiency could not be made at that time on the basis of these symptoms or other laboratory data. The urinary excretions furnished the only unequivocal evidence of thiamine deficiency. On the ninety-eighth day the signs and symptoms and other laboratory data which have been described elsewhere were sufficiently definite to merit a diagnosis of thiamine deficiency without reference to the data on the urinary excretion. When a state of thiamine deficiency has progressed to such a degree that it can be diagnosed from symptoms alone, determination of the urinary excretion has merit as a confirmatory procedure, but in the differentiation between a state of thiamine deficiency similar to that on the twenty-eighth day and other conditions which give rise to like symptoms, determination of the urinary excretion can be the decisive factor.

It is evident from the results presented that, in general, the ordinary excretion affords as much information as to the physiologic state with respect to thiamine as does the test-dose procedure. It is of value, however, to have the results of both determinations when possible and, of course, it is necessary to determine the ordinary excretion prior to administration of the test dose when twentyfour-hour collections of urine are made.

It is to be noted that the usual consequence of a restriction of the dietary intake of thiamine to 450 micrograms or less is a rapid fall in the values for the ordinary excretion of thiamine during twenty-four hours and in the recovery of the test dose in the urine. Since there is this close correlation between immediate intake and excretion both before and after a test dose, an estimate of the duration of the deficient intake of thiamine cannot be made on the basis of excretion studies.

We have previously reported that the excretions by Subjects 1, 2, 3 and 4 remained at essentially a normal level for approximately three months after restriction of the thiamine intake. The amount of thiamine excreted by all other subjects rapidly decreased when the ordinary diet was changed to one which furnished an inadequate amount of thiamine. We are unable to explain the divergence of our first observations from our later ones which are in agreement with the observations of other investigators $(15,16,17)$.
The foregoing statements do not necessarily apply, however, when the intake of thiamine has been much greater than the minimal requirement for a month or more. Subjects 5 and 6 (Table III) furnish examples of what the excretions may be under these circumstances. Subjects 5 and 6 received $7.5 \mathrm{mgm}$. of thiamine chloride for thirtyseven days. Then they were placed for five days on a diet which furnished 400 micrograms of thiamine and for twenty-two days on a diet which furnished 600 micrograms. The intake of thiamine was thus definitely deficient, as judged by all the criteria available, for twenty-seven days, yet at the end of that period the twenty-four-hour excretions were 140 and 107 micrograms, respectively, and 20 per cent of the test dose was recovered in the urine. These values ordinarily would be considered indicative of an adequate intake. When these values are compared with the corresponding values of 88,38 and 65 micrograms for Subjects 12,13 and 16 and with recoveries of 14 to 17 per cent of the test dose, it is obvious that Subjects 5 and 6 must have been drawing upon a store of thiamine. In these instances the excretions and responses to the test dose did not indicate the inadequate intake but did show adequate nutrition with respect to thiamine of these two subjects.

The results obtained with Subjects 5, 6, 8 and 9 (Table I), after treatment with more than 10 mgm. of thiamine daily for thirty-three days, also give evidence of a retention of thiamine which resulted in elevated twenty-four hour excretions after five days on a diet which furnished $850 \mathrm{mi}$ crograms of thiamine and which also resulted in elevated, although substandard, responses to the test-dose procedure after a further period of five days with an intake of 150 micrograms. The decrease in the response to the test-dose procedure during the latter period again illustrates the usual close relation between the level of intake of thiamine and this response.

As previously mentioned, the data in Table III suggest that the minimal intake of thiamine to supply the physiologic needs of five of these subjects was 800 micrograms, or $0.4 \mathrm{mgm}$. per thousand calories. At this level, the average value for the twenty-four-hour excretion was 119 micrograms and the average recovery of the test dose was 21 per cent. Allowing for inaccuracies in the 
TABLE IV

Constant thiamine diet II: Sample diet used on day preceding and day of test. Thiamine content of composite diet 850 micrograms (thiochrome method)

\begin{tabular}{|c|c|c|c|c|c|c|c|}
\hline Food & $\begin{array}{c}\text { State } \\
\text { of } \\
\text { preparation }\end{array}$ & Grams & $\begin{array}{c}\text { Amount, } \\
\text { household } \\
\text { measure }\end{array}$ & Carbohydrate & Protein & Fat & Calories \\
\hline Oatmeal & Cooked & $\begin{array}{c}150 \\
(20 \mathrm{dry})\end{array}$ & $\frac{2}{3}$ cup, cooked & $\begin{array}{c}\text { grams } \\
14\end{array}$ & $\begin{array}{c}\text { grams } \\
3\end{array}$ & $\begin{array}{c}\text { grams } \\
1\end{array}$ & 77 \\
\hline $\begin{array}{l}\text { Orange } \\
\text { Bread, white }\end{array}$ & $\begin{array}{l}\text { Fresh } \\
\text { Commercial }\end{array}$ & $\begin{array}{l}100 \\
120\end{array}$ & $\begin{array}{l}1 \text { medium size } \\
4 \text { average slices }\end{array}$ & $\begin{array}{l}11 \\
63\end{array}$ & 11 & 2 & $\begin{array}{r}48 \\
314\end{array}$ \\
\hline $\begin{array}{l}\text { Butter } \\
\text { Cream } \\
\text { Milk } \\
\text { Beef, medium fat } \\
\text { Potato } \\
\text { Tomato } \\
\text { Carrots } \\
\text { Peaches } \\
\text { Eggs } \\
\text { Cherries } \\
\text { Jelly } \\
\text { Lemon juice } \\
\text { Sugar }\end{array}$ & $\begin{array}{l}\text { As purchased } \\
20 \text { per cent } \\
\text { As purchased } \\
\text { Roasted } \\
\text { Baked } \\
\text { Canned } \\
\text { Canned } \\
\text { Canned } \\
\text { Cooked } \\
\text { Canned } \\
\text { As purchased } \\
\text { Fresh } \\
\text { As purchased }\end{array}$ & $\begin{array}{r}30 \\
100 \\
100 \\
70 \\
200 \\
100 \\
100 \\
100 \\
100 \\
100 \\
20 \\
25 \\
50\end{array}$ & $\begin{array}{l}3 \text { squares } \\
\frac{1}{2} \text { glass } \\
\frac{1}{2} \text { glass } \\
2 \frac{1}{3} \text { ounces } \\
2 \text { medium size } \\
\frac{1}{2} \text { cup } \\
\frac{1}{2} \text { cup } \\
2 \text { small halves } \\
2 \text { } \\
\frac{1}{2} \text { cup } \\
1 \text { tablespoon } \\
2 \text { tablespoons } \\
3 \text { tablespoons }\end{array}$ & $\begin{array}{r}4 \\
5 \\
38 \\
4 \\
8 \\
18 \\
\\
29 \\
13 \\
2 \\
50\end{array}$ & $\begin{array}{r}3 \\
4 \\
21 \\
4 \\
1 \\
1 \\
13 \\
1\end{array}$ & $\begin{array}{r}24 \\
20 \\
4 \\
13\end{array}$ & $\begin{array}{r}216 \\
208 \\
72 \\
201 \\
168 \\
20 \\
36 \\
72 \\
160 \\
120 \\
52 \\
8 \\
200\end{array}$ \\
\hline Total & & & & 259 & 63 & 76 & 1972 \\
\hline
\end{tabular}

method of analysis and individual variations, we conclude that if the intake of thiamine on the day of test is approximately 1000 micrograms, and if the excretion during twenty-four hours is 100 \pm 10 micrograms or more and the recovery of the test dose is at least $20 \pm 2$ per cent, the nutrition with respect to thiamine is sufficient for minimal needs.

We have considered elsewhere (11) the thiamine requirement of man and concluded on the basis of clinical evidence that $0.5 \mathrm{mgm}$. per thousand calories was a minimum. Considering the difficulties and unavoidable errors involved, this value is in good agreement with the figure of 0.4 mgm. suggested by this study of the excretion of thiamine. Fine distinctions cannot be made between various levels of intake on the basis of excretory data or of clinical observations.

Our data and those of other investigators show an intimate relation between the intake of thiamine and the urinary excretion when the intake is reasonably close to the physiologic requirements. This relation requires that the intake of thiamine should be controlled during the study of the excretion and on the day prior to the study. An intake of approximately the minimal daily requirement is desirable in order to avoid either a deficiency or an excess. In Table IV is presented a sample diet which is suitable for this purpose since it furnishes approximately 2000 calories and 850 micrograms of thiamine.

\section{SUMMARY AND CONCLUSIONS}

1. Determination of the urinary excretion of thiamine during twenty-four hours usually gives as much information as the test-dose procedure. Either determination or a combination of the two is a valuable laboratory adjunct to the clinical diagnosis of the state of nutrition with respect to thiamine if the intake of thiamine is controlled during the time of the test.

2. Control of the diet during and prior to the test-dose procedure is necessary for a reliable interpretation of the results. A balanced diet which contains 800 to 900 micrograms (Table IV) of thiamine is suitable for this purpose.

3. The urinary excretion of thiamine describes the intake of thiamine during and just prior to the time of the test unless there has recently been an abrupt change of some magnitude in the intake.

4. The test dose should be near the physiologic requirement for thiamine and should be given parenterally to insure complete and prompt absorption. Intramuscular injection of $1 \mathrm{mgm}$. of thiamine chloride is a satisfactory procedure. 
5. The data on excretion of thiamine indicate that $0.4 \mathrm{mgm}$. of thiamine per thousand calories of diet was the minimal requirement for five women under the conditions of this study. At this level of intake the average excretion during twenty-four hours was 119 micrograms and there was a recovery of 21 per cent of the test dose. Excretion of $100 \pm 10$ micrograms or more in twenty-four hours and recovery of at least $20 \pm 2$ per cent of the test dose are considered evidence of adequate nutrition with respect to thiamine.

6. Two subjects gave evidence of a considerable storage of thiamine after receiving $7.5 \mathrm{mgm}$. of thiamine chloride for thirty-seven days, as judged by the ordinary excretions of thiamine and the responses to the test dose following a subsequent period of twenty-seven days during which the intake of thiamine was inadequate.

\section{BIBLIOGRAPHY}

1. Harris, L. J., and Leong, P. C., Vitamins in human nutrition; the excretion of vitamin $B_{1}$ in human urine and its dependence on the dietary intake. Lancet, 1936, 1, 886.

2. Robinson, W. D., Melnick, D., and Field, H., Jr., Urinary excretion of thiamine in clinical cases and the value of such analyses in the diagnosis of thiamine deficiency. J. Clin. Invest., 1940, 19, 399.

3. Neuweiler, W., Aneurinstoffwechsel in Schwangerschaft und Wochenbett. Arch. f. Gynäk., 1939, 169, 19.

4. von Drigalski, W., Zerstörung von parenteral zugeführtem Vitamin $B_{1}$, zugleich غंn Beitrag zur Frage einer Vitamin $B_{2}$-Belastung. Klin. Wchnschr., 1939, 18, 99.

5. Hildebrandt, A., Zur Frage der Vitamin $B_{1}$-Belastung beim Menschen. Deutsche med. Wchnschr., 1939, 65, 639.

6. Pollack, H., Dolger, H., Ellenberg, M., and Cohen, S., A test proposed to measure vitamin $B_{1}$ satura- tion in humans. Proc. Soc. Exper. Biol. and Med., 1940, 44, 98.

7. Schroeder, H., Untersuchungen über den stoff wechsel des $B_{1}-V i t a m i n s$ am Gesunden und Kranken. Klin. Wchnschr., 1939, 18, 148.

8. Wang, Y. L., and Harris, L. J., Methods for assessing the level of nutrition of the human subject. Estimation of vitamin $B_{1}$ in urine by the thiochrome test. Biochem. J., 1939, 33, 1356.

9. Williams, R. D., Mason, H. L., and Smith, B. F., Induced vitamin $B_{\mathbf{1}}$ deficiency in human subjects. Proc. Staff Meet., Mayo Clin., 1939, 14, 787.

10. Williams, R. D., Mason, H. L. Wilder, R. M., and Smith, B. F., Observations on induced thiamine (vitamin $B_{1}$ ) deficiency in man. Arch. Int. Med., 1940, 66, 785.

11. Williams, R. D., and Mason, H. L., Further observations on induced thiamine (vitamin $B_{1}$ ) deficiency and thiamine requirement of man: Preliminary report. Proc. Staff Meet., Mayo Clin., 1941, 16, 433.

12. Hennessy, D. J., and Cerecedo, L. R., The determination of free and phosphorylated thiamin by a modified thiochrome assay. J. Am. Chem. Soc., 1939, 61, 179.

13. Hennessy, D. J., Chemical methods for the determination of vitamin $B_{1}$. Indust. and Engin. Chem. (Analyt. Ed.), 1941, 13, 216.

14. Mason, H. L., and Williams, R. D., The effect of ingestion of nicotinic acid on the determination of thiamine in urine by the thiochrome method. J. Biol. Chem., 1941, 140, 417.

15. Melnick, D., Field, H., Jr., and Robinson, W. D., Quantitative chemical study of the urinary excretion of thiamine by normal individuals. J. Nutrition, 1939, 18, 593.

16. Wang, Y. L., and Yudkin, J., Assessment of the level of nutrition. Urinary excretion of aneurin at varying levels of intake. Biochem. J., 1940, 34, 343.

17. Goudsmit, J., and Westenbrink, H. G. K., Determination of aneurin (= vitamin $B_{1}$ ) in urine by the thiochrome method. Nature, 1937, 139, 1108. 